\title{
Serum concentrations of acute phase proteins and immunoglobulins of calves with rotavirus diarrhea
}

[Concentração sérica de proteinas de fase aguda e imunoglobulinas em bezerros acometidos por diarreia por rotavírus]

\author{
T.G. Rocha ${ }^{1}$, F.D.F. Silva ${ }^{2}$, C. Bortoletto ${ }^{1}$, D.G. Silva ${ }^{1}$, M.G. Buzinaro ${ }^{1}$, \\ L.F. Zafalon $^{3}$, J.J. Fagliari ${ }^{1}$ \\ ${ }^{1}$ Universidade Estadual Paulista - UNESP - Jaboticabal, SP \\ ${ }^{2}$ Universidade de São Paulo - USP - São Paulo, SP \\ ${ }^{3}$ Embrapa Pecuária Sudeste - São Carlos, SP
}

\begin{abstract}
The aim of the present study was to characterize changes in acute phase protein levels according to the occurrence of rotavirus diarrhea in calves in the first month of life. Blood and fecal samples were taken before colostrum intake and at 1,2, 7, 15, 21 and 30 days of age from 24 Holstein calves allotted in three experimental groups: calves that did not present diarrhea (group A), calves that presented diarrhea, but tested negative for rotavirus in feces (group B), and calves that presented diarrhea and tested positive for rotavirus in feces (group C) (experiment 1). When the animals presented episodes of diarrhea, blood and fecal samples were taken at 24-hour intervals until the end of clinical signs (experiment 2). Serum proteins were separated by SDS-PAGE technique and rotavirus in feces was detected by PAGE. Data of experiment 1 were analyzed by ANOVA and Tukey's test, considered significant at $\mathrm{P}<0.05$. Data of experiment 2 were subjected to the HSD test. Total protein, globulins, and IgG concentrations were lower in group $\mathrm{C}$ than in groups $\mathrm{A}$ and $\mathrm{B}$. Ceruloplasmin and transferrin levels were higher in group $\mathrm{C}$ than in groups A and B. Serum concentrations of haptoglobin and $\alpha_{1}$-acid glycoprotein did not differ significantly between groups throughout the experimental period. Calves presented diarrhea between 10.4 and 14.6 days of age in group B, and between 10.3 and 14.6 days of age in group C. In the moments of diarrhea manifestation, least square means of IgA, haptoglobin and $\alpha_{1}$-acid glycoprotein concentrations did not differ significantly between groups $\mathrm{B}$ and $\mathrm{C}$, but ceruloplasmin and transferrin concentrations were higher in group $\mathrm{C}$ than in group $\mathrm{B}$, as opposed to what occurred with IgG levels. These findings show that optimizing passive immunity transfer of immunoglobulins decrease the likelihood of calves developing diarrhea caused by rotavirus. In addition, ceruloplasmin presents characteristics of a biomarker of rotavirus infection in calves.
\end{abstract}

Keywords: bovine rotavirus, bovine neonatal diarrhea, serum proteinogram, ceruloplasmin

\section{RESUMO}

O objetivo do presente estudo foi avaliar alterações nos teores de proteínas de fase aguda de acordo com a ocorrência de diarreia por rotavírus em bezerros no decorrer do primeiro mês de vida. Amostras de sangue e fezes de 24 bezerros da raça Holandesa foram coletadas antes da ingestão de colostro e com um, dois, sete, quinze, vinte um e trinta dias de idade, sendo os bezerros alocados em três grupos: bezerros que não apresentaram diarreia (grupo A), bezerros que apresentaram diarreia, mas foram negativos para a detecção de rotavírus nas fezes (grupo B) e bezerros que apresentaram diarreia e foram positivos para detecção de rotavírus nas fezes (grupo C) (experimento 1). Sempre que os animais apresentavam episódio de diarreia, amostras de sangue e fezes eram coletadas em intervalos de 24 horas até o término dos sinais clínicos (experimento 2). As proteínas séricas foram separadas por meio da técnica de SDS-PAGE e a pesquisa de rotavírus nas fezes foi realizada por meio da técnica de PAGE. Os resultados do experimento 1 foram analisados por meio de ANOVA e do teste de Tukey, considerado significativo quando $P<0,05$. Os dados do

Recebido em 5 de setembro de 2014

Aceito em 11 de fevereiro de 2016

E-mail: thaisgrocha@yahoo.com.br 
experimento 2 foram submetidos ao teste HSD. Os teores de proteina total, globulinas e IgG foram menores no grupo $C$ que nos grupos $A$ e $B$, os teores de ceruloplasmina e transferrina foram maiores no grupo $C$ que nos grupos $A$ e $B$ e as concentrações séricas de haptoglobina e $\alpha_{1}$-glicoproteína ácida não diferiram significativamente entre grupos. Os bezerros manifestaram diarreia, em média, com 10,4 a 14,6 dias de idade no grupo B e com 10,3 a 14,6 dias de idade no grupo $C$. Nos momentos de manifestação de diarreia, os teores de IgA, haptoglobina e $\alpha_{1}$-glicoproteína ácida não diferiram significativamente entre os grupos $B$ e $C$, mas os teores de ceruloplasmina e transferrina foram maiores no grupo $C$ que no grupo $B$, oposto ao verificado para $o$ teor de IgG. Esses achados mostram que a otimização da transferência de imunidade passiva de imunoglobulinas reduz a probabilidade de os animais apresentarem diarreia por rotavírus. Adicionalmente, a ceruloplasmina apresenta características de um biomarcador da infecção por rotavírus em bezerros.

Palavras-chave: rotavirus bovino, diarreia neonatal bovina, proteinograma sérico, ceruloplasmina

\section{INTRODUCTION}

Bovine neonatal diarrhea is one of the most important disease complexes that affect calves worldwide, and one of the main causes of morbidity and mortality in young animals, resulting in economic losses due to the costs of treatment and prophylaxis, augmented susceptibility to other infections, impaired development of animals, and death (Radostits et al., 2007).

This multifactorial process may be caused by many pathogens, such as bovine rotavirus (BRV), coronavirus, Escherichia coli K99 (E. coli), and Cryptosporidium parvum. García et al. (2000) reported that they detected these microorganisms in $75 \%$ to $95 \%$ of cases of intestinal infections in calves younger than one month old, and found a close association between the presence of these agents and the occurrence of diarrhea. Previous studies of the simultaneous prevalence of multiple etiological agents of bovine diarrhea in calves found a prevalence of $20 \%$ of bovine rotavirus in Belgium, 25.1\% in Brazil, and 59\% in Switzerland (De Graaf et al., 1999; Langoni et al., 2004; Uhde et al., 2008, respectively). These reports demonstrate the epidemiological importance of BRV as an etiological agent of bovine neonatal diarrhea.

In neonatal calves, the mortality rate of BRV diarrhea may reach up to $80 \%$, but most reports suggest it is about $5-20 \%$, mostly in calves that received an insufficient volume of high quality colostrum, animals affected by other pathogens such as enteropathogenic E. coli, or animals living in stressful conditions (Dhama et al., 2009).
The acute phase response occurs as an early reaction of the host to tissue damage or infection through the induction of cytokines, resulting in the production of specific serum proteins by the liver, known as acute-phase proteins (APPs) (Baumann and Gauldie, 1994). APPs may serve as an alternative means of monitoring individual animal or herd health, due to the increase in their concentration during acute phase response, making them useful tools to characterize and quantify reaction to inflammation or infection (Murata et al., 2004). Serum proteinogram is a reliable and valid method for the identification and quantification of different protein fractions, including immunoglobulins and APPs. Determination of APPs is one of the methods that can be used to identify animals presenting clinical or subclinical diseases, and among all the different techniques employed for this purpose, polyacrylamide gel electrophoresis containing sodium dodecyl sulphate (SDS-PAGE) offers the advantage of allowing for the identification and quantification of larger numbers of specific protein fractions (Cole et al., 1997; Fagliari et al., 2006).

The aim of this study was to characterize changes in serum protein concentrations pursuant to the occurrence of diarrhea in neonatal calves in the first month of life, as well as to verify the existence of marker proteins in animals affected by rotavirus diarrhea.

\section{MATERIALS AND METHODS}

The experimental design was approved by the Animal Research Ethics Committee of the College of Veterinary Medicine of São Paulo State University (Unesp) in Jaboticabal, under protocol number 015110/10. 
Twenty-four Holstein calves were allotted in three experimental groups, according to the occurrence of diarrhea in the first month of life, as follows: group A - eight calves that did not present diarrhea or rotavirus infection (control group); group B - eight calves that presented diarrhea, but tested negative for rotavirus in feces; group C - eight calves that presented diarrhea and tested positive for rotavirus in feces.

Blood samples were taken by jugular venipuncture before colostrum intake (moment 0 ) and at 1, 2, 7, 15, 21 and 30 days of age (experiment 1). Also, whenever the animals presented episodes of diarrhea, blood samples were collected at 24-hour intervals until the end of clinical signs (experiment 2). Blood samples from experiments 1 and 2 were centrifuged and the serum obtained was stored at $-20^{\circ} \mathrm{C}$ until the moment of analysis. Fecal samples were collected directly from the rectum on the same occasions as blood samples, and were stored in plastic bags at $-20^{\circ} \mathrm{C}$ until analysis. Whenever calves manifested diarrhea (experiment 2), the first day clinical signs observed was considered moment 1 , and so on, regardless of the animal's age.

Serum proteins were electrophoretically separated in polyacrylamide gels containing sodium dodecyl sulphate (SDS-PAGE), using the technique described by Laemmli (1970). After separation of the protein fractions, the gel was stained with a solution of $0.2 \%$ coomassie blue. Concentrations of protein fractions were determined by computer-assisted densitometry (Shimadzu CS9301, Tokyo, Japan). Reference markers (Sigma, St. Louis, MO, USA) with molecular weights of $24 \mathrm{kDa}, 29 \mathrm{kDa}, 36 \mathrm{kDa}$, $45 \mathrm{kDa}, 55 \mathrm{kDa}, 66 \mathrm{kDa}, 97 \mathrm{kDa}, 116 \mathrm{kDa}$, and $205 \mathrm{kDa}$ were used to identify protein fractions as well as electrophoretic mobility of purified ceruloplasmin, transferrin, haptoglobin, $\alpha 1$-antitrypsin, $\alpha 1$-acid glycoprotein, and immunoglobulin $\mathrm{G}$.

Concentrations of total protein and albumin were determined spectrophotometrically, using commercial reagents (Labtest Diagnostica, Lagoa Santa, Minas Gerais, Brazil). Globulin levels were determined arithmetically based on the difference between total protein and albumin concentrations in serum.
Rotavirus in feces was detected by polyacrylamide gel electrophoresis, as recommended by Herring et al. (1982), with a few modifications suggested by Pereira et al. (1983). The data obtained in experiment 1 were analyzed by ANOVA and the differences between groups were compared by Tukey's test, considered significant at $\mathrm{P}<0.05$. The data obtained during the moments of diarrhea manifestation (experiment 2) were subjected to the HSD test using the Statistical Analysis System (SAS) software.

\section{RESULTS}

In experiment 1, although there was no significant difference between groups, the total protein concentration (Table 1) was lower in calves testing positive for rotavirus in feces (group C) than in groups $\mathrm{A}$ and $\mathrm{B}$ at all the evaluated moments - this tendency was also observed for globulin levels (Table 1). In addition, the globulin concentration was significantly lower in group $\mathrm{C}$ than in groups $\mathrm{A}$ and $\mathrm{B}$ on the second day of life. After colostrum intake, both parameters increased significantly in all the groups when compared to moment 0 , followed by a gradual decrease until 30 days of age.

Immunoglobulin A (IgA) concentration (Table 1) did not differ significantly between groups; between moments, the levels of this immunoglobulin increased gradually from birth to 30 days of age.

Ceruloplasmin concentrations (Table 1) differed significantly between groups at 7 days of age, when a higher level of this acute phase protein was observed in group $\mathrm{C}$ than in groups $\mathrm{A}$ and $\mathrm{B}$, and at 30 days of age, when a higher concentration of ceruloplasmin was observed in group A and a lower level in group B. Between moments, the lowest concentrations of ceruloplasmin was observed in the first days of life and the highest at 30 days of age in all the groups.

Transferrin levels (Table 1) were higher in group $\mathrm{C}$ and lower in group $\mathrm{B}$ only at 30 days of age. Between moments, the highest concentration of transferrin occurred at 7 days of age and the lowest at birth in groups $\mathrm{A}$ and $\mathrm{C}$, and at 30 days of age in group $\mathrm{B}$. 
Table 1. Mean values and standard-deviations of serum protein concentrations in Holstein calves not presenting diarrhea (group A), presenting diarrhea but testing negative for rotavirus in feces (group B) and presenting diarrhea and testing positive for rotavirus in feces (group C) before colostrum intake (moment 0 ) and at 1, 2, 7, 15,21 and 30 days of life

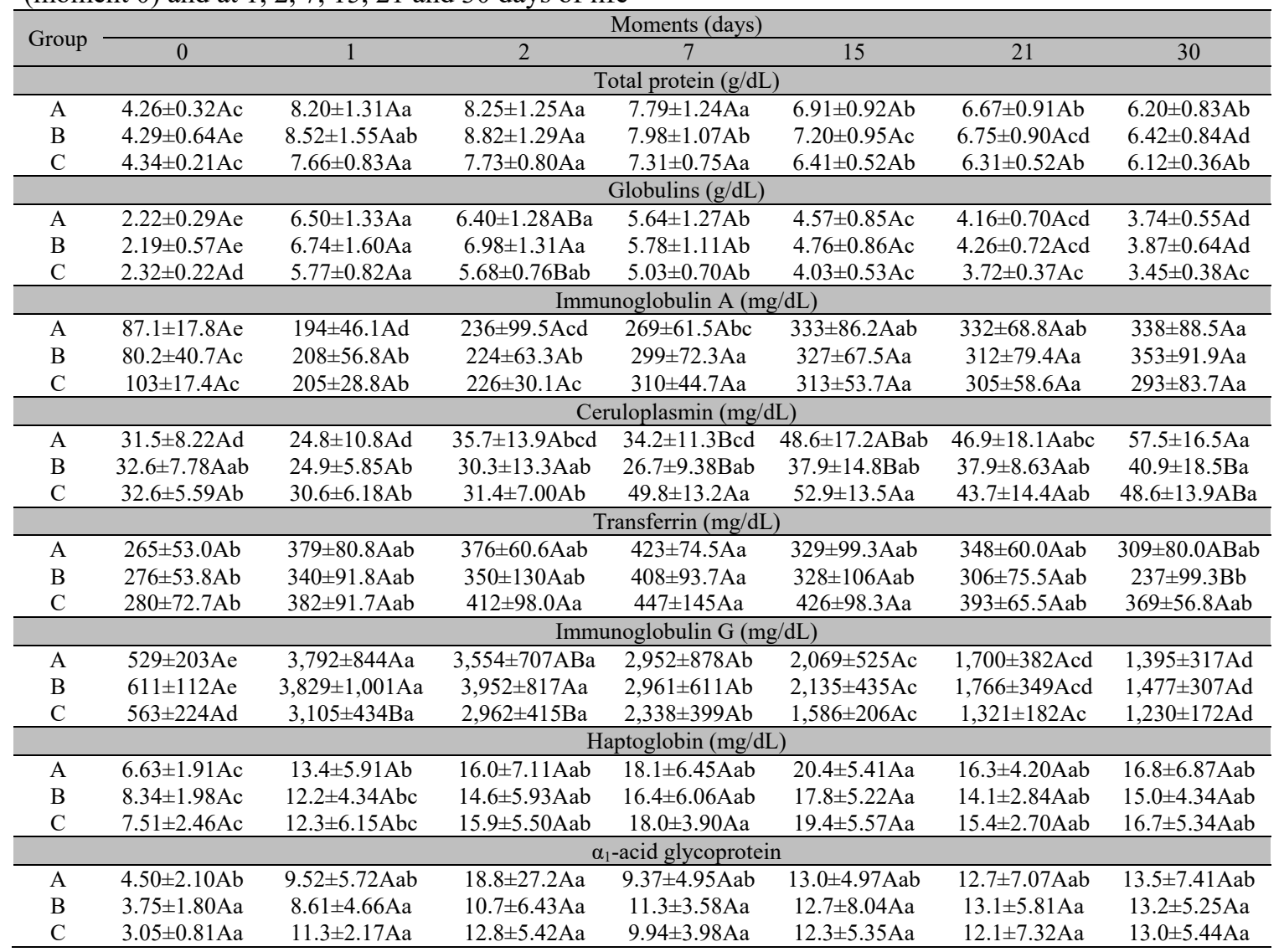

Mean values followed by the same upper case letters in the same column and lower case letter in the same line do not differ significantly according to Tukey test $(\mathrm{P}<0.05)$.

Before colostrum intake, the groups showed no significant difference in immunoglobulin $G$ (IgG) concentrations (Table 1). On days 1 and 2 of life, groups A and B showed significantly higher levels of this protein than group $\mathrm{C}$. Between moments, the lowest IgG concentration was found immediately after birth, and the highest at 1 and 2 days of life, after colostrum intake. IgG levels then decreased gradually until 30 days of age.

Serum concentrations of haptoglobin (Table 1) did not differ significantly between groups throughout the experimental period. Between moments, the concentration of this protein increased after colostrum intake, with the highest levels found at 15 days of age in all three groups. $\alpha_{1}$-acid glycoprotein levels (Table 1) did not differ significantly between groups or moments in groups $\mathrm{B}$ and $\mathrm{C}$ in the first month of life. In group A, the lowest concentration of this APP was found at birth and the highest at 2 days of age.

When evaluating the period of diarrhea manifestation (days 1 to 7 ) - experiment 2 - it was interesting to note that although the total protein concentration (Table 2) in group B was significantly higher than in group $\mathrm{C}$ only on the second day of diarrhea manifestation, this tendency was observed at all the moments evaluated. 
Table 2. Least square mean values of serum protein concentrations in Holstein calves that tested negative (group B) or positive (group C) for rotavirus in feces from the first to the seventh day of diarrhea manifestation

\begin{tabular}{|c|c|c|c|c|c|c|c|}
\hline \multirow{2}{*}{ Groups } & \multicolumn{7}{|c|}{ Moments (days) } \\
\hline & 1 & 2 & 3 & 4 & 5 & 6 & 7 \\
\hline & \multicolumn{7}{|c|}{ Total protein $(\mathrm{g} / \mathrm{dL})$} \\
\hline B & $7.67 \mathrm{~A}$ & $7.63 \mathrm{~A}$ & $7.25 \mathrm{~A}$ & $7.18 \mathrm{~A}$ & $6.97 \mathrm{~A}$ & $7.08 \mathrm{~A}$ & $6.77 \mathrm{~A}$ \\
\hline \multirow[t]{2}{*}{$\mathrm{C}$} & $7.29 \mathrm{~A}$ & $7.01 \mathrm{~B}$ & $6.86 \mathrm{~A}$ & $6.53 \mathrm{~A}$ & $6.55 \mathrm{~A}$ & $6.45 \mathrm{~A}$ & $6.26 \mathrm{~A}$ \\
\hline & \multicolumn{7}{|c|}{ Globulins (g/dL) } \\
\hline B & $5.31 \mathrm{~A}$ & $5.24 \mathrm{~A}$ & $4.91 \mathrm{~A}$ & $4.83 \mathrm{~A}$ & $4.62 \mathrm{~A}$ & $4.68 \mathrm{~A}$ & $4.41 \mathrm{~A}$ \\
\hline \multirow[t]{2}{*}{$\mathrm{C}$} & $4.83 \mathrm{~B}$ & $4.55 \mathrm{~B}$ & $4.48 \mathrm{~B}$ & 4.19 B & $4.03 \mathrm{~B}$ & $4.07 \mathrm{~A}$ & $4.02 \mathrm{~A}$ \\
\hline & \multicolumn{7}{|c|}{ Ceruloplasmin (mg/dL) } \\
\hline B & $48.4 \mathrm{~A}$ & $43.8 \mathrm{~B}$ & $39.0 \mathrm{~B}$ & $36.2 \mathrm{~B}$ & $41.9 \mathrm{~A}$ & $44.7 \mathrm{~A}$ & $50.5 \mathrm{~A}$ \\
\hline \multirow[t]{2}{*}{$\mathrm{C}$} & $55.2 \mathrm{~A}$ & $59.6 \mathrm{~A}$ & $56.3 \mathrm{~A}$ & $53.1 \mathrm{~A}$ & $57.7 \mathrm{~A}$ & $57.7 \mathrm{~A}$ & $38.4 \mathrm{~A}$ \\
\hline & \multicolumn{7}{|c|}{ Transferrin $(\mathrm{mg} / \mathrm{dL})$} \\
\hline B & $424 \mathrm{~A}$ & $387 \mathrm{~A}$ & $365 \mathrm{~A}$ & $347 \mathrm{~A}$ & $251 \mathrm{~B}$ & $336 \mathrm{~A}$ & $270 \mathrm{~A}$ \\
\hline \multirow[t]{2}{*}{$\mathrm{C}$} & $454 \mathrm{~A}$ & $468 \mathrm{~A}$ & $441 \mathrm{~A}$ & $423 \mathrm{~A}$ & $407 \mathrm{~A}$ & $418 \mathrm{~A}$ & $387 \mathrm{~A}$ \\
\hline & \multicolumn{7}{|c|}{ Immunoglobulin $\mathrm{G}(\mathrm{mg} / \mathrm{dL})$} \\
\hline B & $2,474 \mathrm{~A}$ & $2,479 \mathrm{~A}$ & $2,208 \mathrm{~A}$ & $2,139 \mathrm{~A}$ & $2,036 \mathrm{~A}$ & $2,032 \mathrm{~A}$ & $1,784 \mathrm{~A}$ \\
\hline $\mathrm{C}$ & $2,127 \mathrm{~B}$ & $1,908 \mathrm{~B}$ & $1,846 \mathrm{~B}$ & $1,750 \mathrm{~B}$ & $1,751 \mathrm{~A}$ & $1,672 \mathrm{~A}$ & $1,594 \mathrm{~A}$ \\
\hline
\end{tabular}

Least square mean values followed by the same letter in the same column do not differ according to the HSD test $(\mathrm{P}<0.05)$

From the first to the fifth days of manifestation of clinical signs of diarrhea, group B showed higher globulin concentrations than group $\mathrm{C}$ (Table 2).

Serum concentrations of IgA throughout the moments of diarrhea manifestation showed no significant difference between groups B and C. Least square means varied from 304 to $352 \mathrm{mg} / \mathrm{dL}$ in group B and from 305 to $323 \mathrm{mg} / \mathrm{dL}$ in group $\mathrm{C}$.

Least square means of ceruloplasmin concentrations (Table 2) from the second to the fourth day of diarrhea were higher in group $\mathrm{C}$ than in group B. On the fifth day of diarrhea, transferrin concentration was significantly lower in group B than in group C (Table 2).

Immunoglobulin $\mathrm{G}$ concentrations (Table 2) were significantly higher in group B than in group $C$ from the first to the fourth days of diarrhea. Albeit not always significant, this difference remained constant throughout the experimental period.

Groups B and C showed no significant difference in haptoglobin and $\alpha_{1}$-acid glycoprotein concentrations in the period of diarrhea manifestation. Least square means of haptoglobin levels varied from 13.1 to $20.2 \mathrm{mg} / \mathrm{dL}$ in group $\mathrm{B}$ and from 15.2 to $19.2 \mathrm{mg} / \mathrm{dL}$ in group $\mathrm{C}$, while $\alpha_{1}$-acid glycoprotein concentrations varied from 11.3 to $13.4 \mathrm{mg} / \mathrm{dL}$ in group $\mathrm{B}$ and from 10.4 to $13.7 \mathrm{mg} / \mathrm{dL}$ in group $\mathrm{C}$

In experiment 2, calves presented diarrhea with an average age of 10.4 to 14.6 days in group B, and 10.3 to 14.6 days in group C (Table 3 ).

Table 3. Age of calves in the beginning and end of diarrhea manifestation period in groups B and $\mathrm{C}$ (experiment 2)

\begin{tabular}{ccccc}
\hline \multirow{2}{*}{$\begin{array}{c}\text { Calf } \\
\text { number }\end{array}$} & \multicolumn{5}{c}{ Groups } \\
\cline { 2 - 5 } & Beginning & End & Beginning & End \\
\hline 1 & 7 & 11 & 7 & 9 \\
2 & 7 & 13 & 7 & 10 \\
3 & 9 & 12 & 9 & 14 \\
4 & 10 & 15 & 10 & 15 \\
5 & 11 & 14 & 11 & 16 \\
6 & 11 & 17 & 11 & 16 \\
7 & 13 & 16 & 12 & 16 \\
8 & 15 & 19 & 15 & 21 \\
Mean & 10.375 & 14.625 & 10.25 & 14.625 \\
\hline
\end{tabular}

\section{DISCUSSION}

From birth to 30 days of age, the serum concentrations of parameters commonly used to evaluate passive immunity transfer, although not always statistically significant, indicated that the total protein, globulins and IgG levels were lower in group $\mathrm{C}$ than in groups $\mathrm{A}$ and $\mathrm{B}$. However, according to Feitosa et al. (2010), calves in all the experimental groups presented 
adequate passive immunity transfer, as indicated by concentrations of IgG measured after colostrum intake. This may indicate that even the slightest decrease in IgG levels acquired through passive immunity transfer may affect the susceptibility of calves to rotavirus infection.

According to Besser et al. (1988), the gastrointestinal tract is the main site for clearance of $\operatorname{IgG}_{1}$ in newborn calves and these immunoglobulins retain some antigenic binding capacity, accounting for mucosal protection from gastrointestinal infection. Specifically referring to rotavirus infection, Westerman et al. (2005) working with non-human primates reported that an increment in concentration of serum $\operatorname{IgG}$ elevated immunoglobulin titers reaching the intestinal lumen and avoided or reduced rotavirus shedding.

There was no significant difference between groups in terms of IgA levels, using SDS-PAGE technique, from birth to 30 days of age. Between moments, there was a gradual increase in $\operatorname{IgA}$ concentrations after colostrum intake, but it was interesting to note that, in group $\mathrm{C}, \operatorname{Ig} \mathrm{A}$ levels decreased at 15 days of age, coinciding with the period of diarrhea manifestation, while in groups $\mathrm{A}$ and $\mathrm{B}$ the $\operatorname{IgA}$ levels increased at this same moment. Similar to our findings, in a study of experimental infection of calves with Salmonella Typhimurium, Ávila (2009) reported no difference between control and infected calves with respect to $\operatorname{IgA}$ concentrations throughout the period of evaluation. Regarding acute phase proteins, throughout the first month of life, the higher concentration of ceruloplasmin in group $\mathrm{C}$ than in groups A and B at 7 and 15 days of age, coinciding with the period in which the animals manifested diarrhea, may be an indicator of increased stimulation for the production of this APP in rotavirus-induced diarrhea when compared to diarrhea caused by other pathogens. The fact that, in Experiment 2, ceruloplasmin levels were also found to be higher in group $\mathrm{C}$ than in group $\mathrm{B}$ corroborates this finding. The increase in ceruloplasmin levels in the $30^{\text {th }}$ day of life in group A, when compared to groups B and $\mathrm{C}$, may be attributable to the occurrence of other pathological conditions not evaluated in this experiment, such as pneumonia.

The use of ceruloplasmin as a diagnostic tool in cattle is still less common than that of haptoglobin and serum amiloid A; however, some studies have shown that this ferroxidase is an indicator of infection in cows (Murata et al., 2004). In other studies evaluating blood serum proteinogram through SDS-PAGE, of calves affected by different infectious causes of diarrhea, Ávila (2009) and Silva et al. (2011) reported an increase in ceruloplasmin concentrations in Holstein calves experimentally infected with Salmonella Typhimurium and Salmonella Dublin, respectively. Hajimohammadi et al. (2013) also found a significant increase in ceruloplasmin levels in calves that presented diarrhea, when compared to healthy animals. Our findings suggest a relationship between the viral origin of diarrhea, the age of calves, and the dynamics of ceruloplasmin evaluated by the SDS-PAGE technique.

Transferrin concentrations in groups A, B, and C, from birth to 30 days of age, were higher in group $\mathrm{C}$ than in groups $\mathrm{A}$ and $\mathrm{B}$, albeit not statistically significant. The same tendency was found in groups $\mathrm{B}$ and $\mathrm{C}$ in the period of diarrhea manifestation. Although transferrin is considered a negative APP - its concentrations tend to decrease in the presence of an acute inflammatory reaction - the increase verified in our study may be related to the viral etiology of diarrhea, since the mechanism of action of transferrin is more relevant in bacterial diseases, in which bonding to iron ions prevents the bacteria from using these ions for growth (Murata et al., 2004).

There was no significant difference in the haptoglobin levels of groups $\mathrm{A}, \mathrm{B}$, and $\mathrm{C}$ from birth to 30 days of age. The values found and the dynamics of this APP after birth are consistent with those reported by Orro et al. (2008), who investigated temporal changes in APP concentrations in newborn dairy calves. In the present study, the increase in haptoglobin concentrations in animals affected by diarrhea in the first month of life (groups B and C Experiment 2) was very discrete, possibly indicating a non-bacterial origin of diarrhea in animals of group B - since Eckersall (2000) reported that haptoglobin is a useful indicator of bovine bacterial infections - or that the etiological agents that affected these animals did not inflict sufficient stimulus to initiate an acute phase response. 
Also, according to Hajimohammadi et al. (2013), who evaluated relationships between acute phase proteins and clinical findings in dairy calf diarrhea, calves that presented severe clinical signs showed a more significant increase in their haptoglobin levels than calves presenting moderate or no systemic clinical signs. All the calves in our study belonged to private farms in which early treatment with antibiotics was initiated as soon as animals present clinical signs, regardless of the cause of diarrhea. In such conditions, all animals in this experiment presented discrete to moderate clinical signs.

Concentrations of $\alpha_{1}$-acid glycoprotein did not differ between groups $\mathrm{A}, \mathrm{B}$, and $\mathrm{C}$ throughout the first month of life, nor did they differ significantly between groups $\mathrm{B}$ and $\mathrm{C}$ in Experiment 2. According to Orro et al. (2008), colostrum intake is the main stimulus for the increase in APPs concentrations in calves, since this secretion contains high concentrations of proinflammatory citokines, which are the main inducers of hepatic production of APPs, thus explaining the increase in haptoglobin, transferrin and $\alpha_{1}$-acid glycoprotein levels after colostrum intake in all the evaluated groups.

Based on these findings, an optimal passive immunity transfer of immunoglobulins decreases the likelihood of calves developing diarrhea caused by rotavirus. In addition, ceruloplasmin measured by SDS-PAGE presents characteristics of a biomarker of rotavirus infection in calves. Experimental infection studies are needed to confirm if this relationship exists for other etiological agents of diarrhea in neonatal calves.

\section{ACKNOWLEDGEMENTS}

To FAPESP (Brazil) for granting financial support and scholarships.

\section{REFERENCES}

ÁVILA, L.G. Estudo clínico, laboratorial e terapêutico da diarréia experimental em bezerros induzida por Salmonella enterica subespécie entérica sorotipo Typhimurium. 2009. 97f. Dissertação (Mestrado em Medicina Veterinária) - Faculdade de Ciências Agrárias e Veterinárias, Universidade Estadual Paulista, Jaboticabal, SP.
BAUMANN, H.; GAULDIE, J. The acute phase response. Immunol. Today, v.15, p.74-80, 1994.

BESSER, T.E.; McGUIRE, T.C.; GAY, C.C. et al. Transfer of functional immunoglobulin $\mathrm{G}$ (IgG) antibody into the gastrointestinal tract accounts for IgG clearance in calves. J. Virol., v.62, p.2234-2237, 1988.

COLE, D.J.; ROUSSEL, A.J.; WHITNEY, M.S. Interpreting a bovine CBC: evaluating the leukon and acute-phase proteins. Vet. Med., v.92, p.470$478,1997$.

DE GRAAF, D.C.; VANOPDENBOSCH, E.; ORTEGA-MORA, L.M. et al. A review of the importance of cryptosporidiosis in farm animals. Int. J. Parasitol., v.29, p.1269-1287, 1999.

DHAMA, K.; CHAUHAN, R.S.; MAHENDRAN, M.; MALIK, S.V.S. Rotavirus diarrhea in bovines and other domestic animals. Vet. Res. Communun., v.33, p.1-23, 2009.

ECKERSALL, P. Recent advances and future prospects for the use of acute phase proteins as markers of disease in animals. Rev. Med. Vet., v.151, p.577-584, 2000.

FAGLIARI, J.J.; RIZOLLI, F.W.; SILVA, S.L.; SILVA, D.G. Proteinograma sérico de bezerros recém-nascidos da raça Holandesa obtido por eletroforese em gel de poliacrilamida. Arq. Bras. Med. Vet. Zootec., v.57, p.1-4, 2006.

FEITOSA, F.L.F.; CAMARGO, D.G.; YANAKA, R. et al. Índices de falha de transferência de imunidade passiva (FTIP) em bezerros holandeses e nelores às 24 e 48 horas de vida: valores de proteína total, de gamaglobulina, de imunoglobulina $G$ e da atividade sérica de gamaglutamiltransferase, para o diagnóstico de FTIP. Pesqui. Vet. Bras., v.30, p.696-704, 2010.

GARCÍA, A.; RUÍZ-SANTA-QUITERIA, J.A.; ORDEN, J.A. et al. Rotavirus and concurrent infection with other enteropathogens in neonatal diarrheic dairy calves in Spain. Compend. Immunol. Microbiol. Infect. Dis., v.23, p.175183, 2000.

HAJIMOHAMMADI, A.; NAZIFI, S.; ANSARILARI, M. et al. Identifying relationships among acute phase proteins (haptoglobin, serum amyloid A, fibrinogen, ceruloplasmin) and clinical findings in dairy calf diarrhea. Comp. Clin. Pathol., v.22, p.227-232, 2013. 
HERRING, A.J.; INGLIS, N.F.; OJEH, C.K. et al. Rapid diagnosis of rotavirus infection by direct detection of viral nucleic acid in silverstained polyacrylamide gels. J. Clin. Microbiol., v.16, p.473-477, 1982.

LAEMMLI, U.K. Cleavage of structural proteins during the assembly of the head bacteriophage T4. Nature, v.277, p.680-685, 1970.

LANGONI, H.; LINHARES, A.C.; AVILA, F.A. et al. Contribution to the study of diarrhea etiology in neonate dairy calves in São Paulo state, Brazil. Braz. J. Vet. Res. Anim. Sci., v.41, p.313-319, 2004.

MURATA, H.; SHIMADA, N.; YOSHIOKA, $M$. Current research on acute phase proteins in veterinary diagnosis: an overview. Vet. J., v.168, p.28-40, 2004.

ORRO, T.; JACOBSEN, S.; LEPAGE, J.P. et al. Temporal changes in serum concentrations of acute phase proteins in newborn dairy calves. Vet. J., v.176, p.182-187, 2008.

PEREIRA, H.G.; AZEREDO, R.S.; LEITE, J.P. et al. Eletrophoretic study of the genome of human rotaviruses from Rio de Janeiro, São
Paulo and Pará, Brazil. J. Hyg., v.90, p.117-125, 1983.

RADOSTITS, O.M.; GAY, C.C.; HINCHCLIFF, K.W.; CONSTABLE, P.D. Veterinary medicine: a textbook of the diseases of cattle, sheep, goats, pigs and horses. Edinburgh: W.B. Saunders, 2007. p.127-160.

SILVA, D.G.; SILVA, P.R.L.; SILVA, P.C.; FAGLIARI, J.J. Serum protein concentrations, including acute phase proteins, in calves experimentally infected with Salmonella Dublin. Pesqui. Vet. Bras., v.31, p.551-554, 2011.

UHDE, F.L.; KAUFMANN, T.; SAGER, H. et al. Prevalence of four enteropathogens in the faeces of young diarrhoeic calves in Switzerland. Vet. Rec., v.163, p.362-366, 2008.

WESTERMAN, L.E.; McCLURE, H.M.; JIANG, B. et al. Serum IgG mediates mucosal immunity against rotavirus infection. Proc. Natl. Acad. Sci. USA, v.102 p.7268-7273, 2005. Disponível em: <http://www.pnas.org/content/ 102/20.toc $>$. Acessado em: 10/01/2015. 